\title{
MEDIA NEWS
}

\section{By Joe Conno}

The Shastri Indo-Canadian Institute has announced details of an exchange pro-
gram whereby Canadian specialists in various aspects of educational technology will visit New Delhi lndia in May of this age exchanges in educational technolog between the two countries, and is spor stitute and the University Grants Com mission of India.

The objectives of the visitation are four educational technologies and innovative programs.

2. To promote discussion on the possible uses of eddcational technology delivering educational programs to met India's need for education and training. 3. To discuss the role of institutions o higher education in the field of distanc technologies. 4. To consider the possibilities of col-
laboration between Canadian and Indian institutions in the development of softThe tentative program has the Cana-
ware dians involved in two weeks of work-

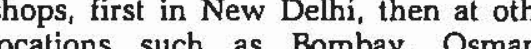
gram are Dr. Bill Winn (Co-ordinator)

University of Calgary Professor Michel Cartier
University of Ouebec Dr. Glen Cartwright
University of McGill Dr. Gary Coldevin
Concordia University Dr. Barry Ellis Calgary Dr. Denis Hlynka
University of Manitoba Dr. Jeff Potter Dr. Ian Taylor
Athabasca University University, and Poona University.
The Canadians participating in the pro-

Computer Technologies for Productive Learning, the Fourth Canadian Symposium on Instructional Technology, Instructional Technology of the National Winnip Council of Canada will be held 21st, 1983. This $n$ called to inform the educational an business communties of recent advan and its applications. Particular attention will be paid to microcomputers, advanced
lelecommunication techniques, videotelecommunication techniques, video-
discs, videotex, and speech generation. For further information contact: Ken Charbonneau,
Conference Services Office Conference Services Office Ottawa, Ont. K1A 0R6 (613) 933-9009

Educators from Austria, Belgium Canada, Denmark,
Hungary, Israel, Italy, Spain, Sweden
Ukrainian S.S.R., U.S.S.R. United Continued on page 3

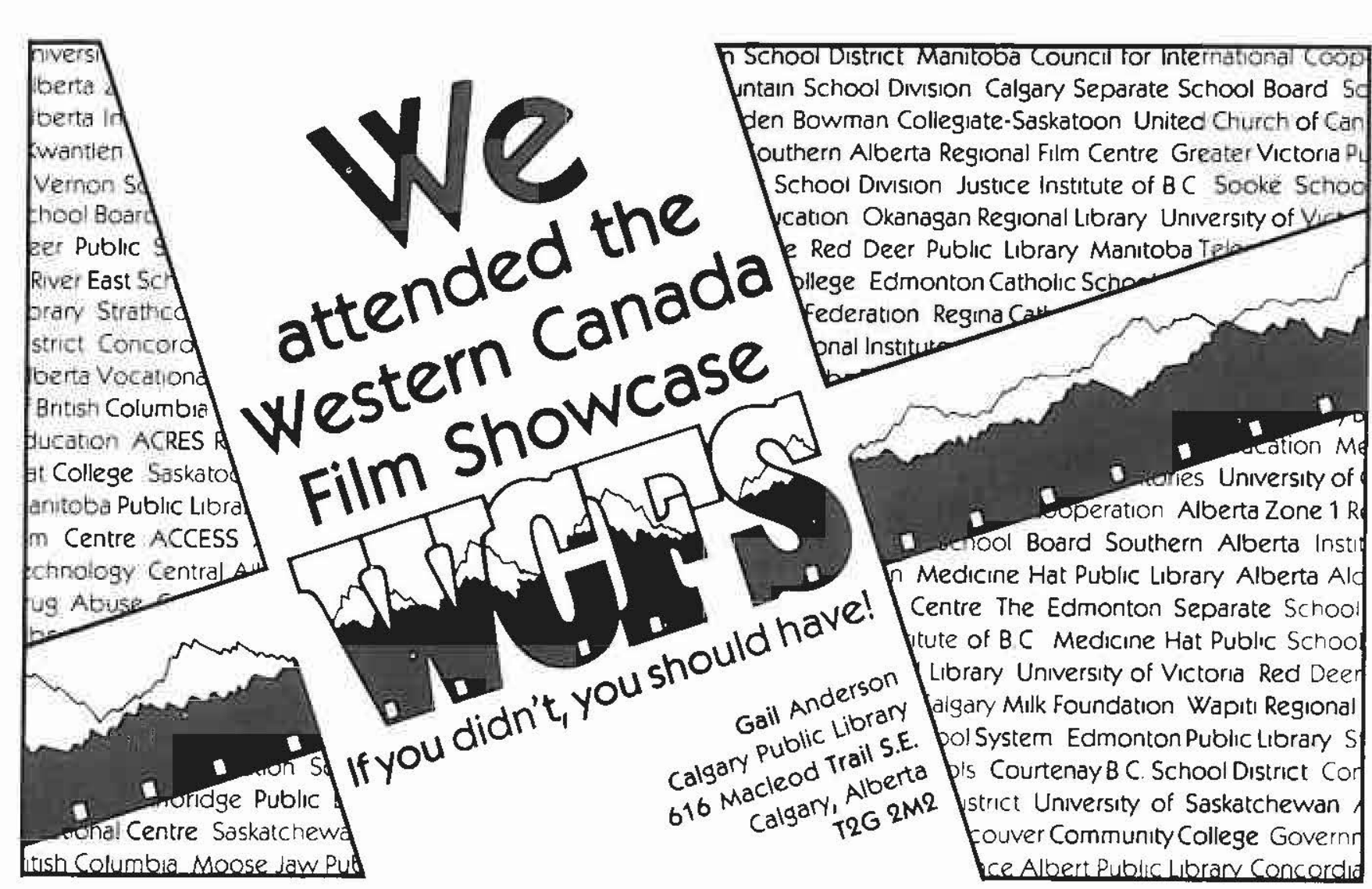

\section{COMPUTER NEWS}

By Rick Kenny

This column is intended to be mainly appening informing members of current pen educational computing scene. ou have news items which you would please forward them to:

$$
\begin{aligned}
& \text { Mr Rick Kenny } \\
& \text { Media Services Group } \\
& \text { Calgary Board of Education } \\
& \text { 3610 - 9th Street S.E. } \\
& \text { Calgary, Alberts } \\
& \text { T2G 3C5 }
\end{aligned}
$$

TV Ontario Academy On Computers Beginning February 16, TV Ontario has been offering a twelve week academy on on television-based do-it-yourself feny is system designed to help the viewer to become familiar with the workings of microcomputer and the related terThe PET, the Aperate one of three micros to develop simple computer programs, to
evaluate and select software for classroom use and to discover available resources. It
includes a series of twelve half-hour television programs, four texts, and continual direction from course developers through correspondence and newsletters.
The programs are being broadcast ove The progranss are being broadcast ove
he TV Ontario network Wednesdays

9:00 p.m. E.S.T. and are repeated the following Saturday at 12:30 p.m. The series is entitled BITS and BYTES and
features Billy Van and Luba Goy. The supporting tests include a TVO Academ Applications Handbook, the Bits and Bytes Resource Book (for the television (Tries) and a Hands-on-Beginner's Manuad microcomputers!. For further information, contact the
TVO Academy on Computers in Educa tion, Part-Time Learning, TV Ontario,
Box 200, Station Q Toronto, Ontario,

Consumers Union and EPIE Launch

Evaluation Service
Consumers Union, publisher of Con sumer Reports and Penny Power
magazines and the EPIE Institute have joined together to develop a new evalua tion service designed to provide schools d evaluations of edu inteph, unbias products. They will providenal compute with detailed reports on computers monitors, printers and software, as well with a monthly school consumer news letter.
The reports will be in the form of regularly updatable and expandable files - to be known as PRO/FILES - and wilt
offer detailed reviews of tested products. on consumer concerns complaints, and hopefully, commendations for good products and services. It will also keep its purchased for testing by Consumers Union and EPIE. Microgram will also be published regularly in the Computing The regular annual subscription to the harter subscription is available for $\$ 195$ U.S. For more information, contact EPIE
Consumers Union, P.O. Box 620, Stony Brook, New York, U.S.A., 11790 .

The U.S. National Diffusion Network The National Diffusion Network (NDN) is an Amenican, federaly-funded systen programs available for adoption by
schools, colleges, and other institutions. It does so by providing funds to these provices to allow institutions and to their seinservice training follow-up assistance, and, in some cases, curriculum materials. All programs are reviewed by a pane perts from the U.S. Department of Eduction. Of interest to Canadians from this ser-
vice may be NDN's catalogue entitled Educational Programs That Work. contains a description of each program, quirements, the director of the particular program, and costs $\$ 5.50$ U.S. per copy prepaid). Write to:

Research and Develory for Educational

Erasable Video Disk Developed An erasable, re-recordable video disk casting Corporation. The Japanese protoype uses a helium neon laser to writ film. The laser beam's heat causes local reversals of the film's magnetic field, thus enabling data to be recorded. The entire disk can be erased by placing it in a stron en over top of old Conventional laser disc systems use a destructive form of recording by punching holes in the
coating of the disk. Street, San Francisco, California, U.S.A

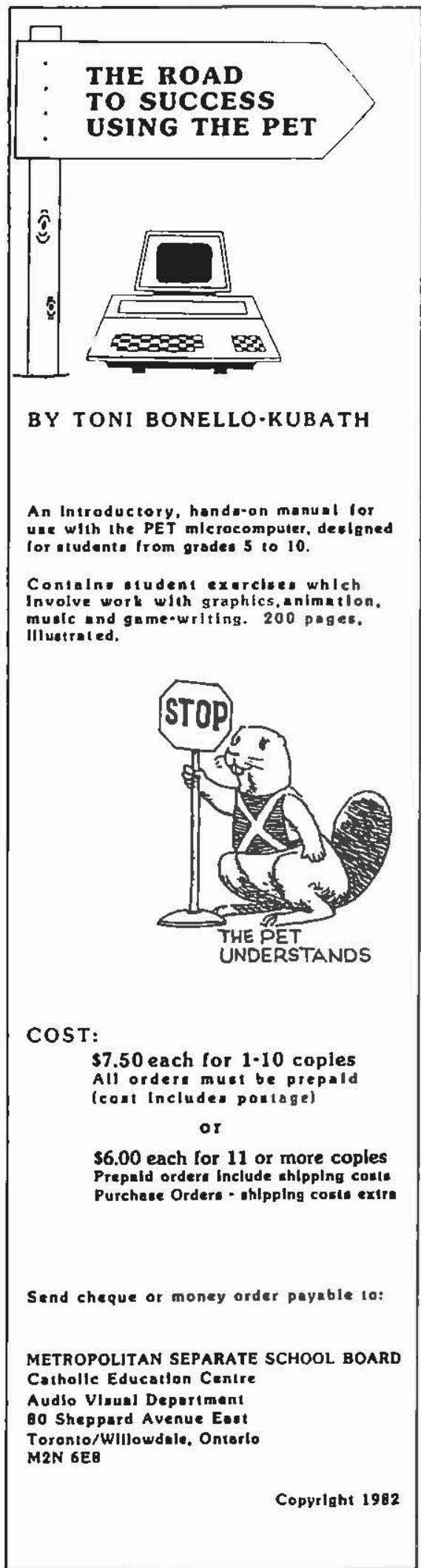

CANADIAN JOURNAL OF EDUCATIONAL COMMUNICATION 
Continued from page 24

Kingdom, U.S.A., will have the oppor-
tunity to compare the educational use of new communication and information technologies through a study being undertaken by the national commissions for Unesco in the countries of the European
region. The first meeting of the three-year joint study was convened by the Canadian and American commissions in collabor tion with the Canadian lead agency - TV commission. TVO is coordinating the first year of the sludy aimed at surveying
educational use of the new technologies, studying their impact and identifyin areas in which further developmen purswit at the nationt resiond and for national levels. For further information contact: Mariette Hogue, Programme Of ficer, Education, Canadian Commission Ottawa, Ontario K1P 5VB (613) 237-3408.

$$
\text { - }
$$

The International Council for Educatheme of its 1982/83 visual literacy series competition for students. The theme is must create a 47 minute film vipetion or slide programme that will tell a story without words. Speech may be used bu the plot must not depend on words. Fur International Council for Educational clodia, Hans G. Kratz,

c/o Hans G. Kratz,
145 Voyageur Estates
52152 Range Road 210
Sherwood Park, Alberta T5G 1AS

"Database publishing", the field which supplies archive information to profesthal customers - pharmacists, paten storage medium. Microfiche discus can contain 6000 documents or 4-megabytes of data. Laser and electron beam lithography is used to reduce the images, disc. A workstation, with Apple II computing power, is used to locate the indexed information and to display it on a high resolution video screen.

$$
\longrightarrow
$$

The Toronto International Centre is the site for Compter Fair 1983 on June 23rd tress microconpur applications in telecommunications, education, word processing, graphics, music, games,
languages, database management. Lecures, seminars and a large Lhibi tures, seminars, and a large
display will highlight the fair.
For further information contact

Debbie Bannon

Computer Fair 2283 Queen St. E.,
Toronto, Ont. M4E 1G6 (416) 690-9666

SaskMedia, a Crown corporation established in 1974 to produce and dissolved March 31, Gary Lane, the
ditson, minister responsible, announced Jan. 19 ,
The government will continue to distribute educational materials, such as transparencies, but the private sector will be inviled to take over production, Lane Cabinet decided to get rid of the Saskal Cowar established in September to assess the corFlation's performance. said. The corporation's assets, including the film and lape library, and 40 of the 64 employees will be transferred to the tained as a separate es will be main. department until more permanent accombe made to acomade, and allempls will 24 employees elsewhere in the government, Lane said in a release.

The government will try to encourage privale pro allowing seducalional pro facilities at a favorable cost, the minister said. "The private sector can effectively ful: fill many of the government requirements
for the production of educational programs, whereas the production services of SaskMedia have for some time been the object of severe criticism on the part of
dissatisfied customers and private sector competitors alike."
-Reprinted from the Saskatoon StarPhoenix, Jan. 19, 1983.

\section{Amrec}

NAME TITLE ADDRESS $1+1,1,1,1,1,1,1,1,1,1,1,4$

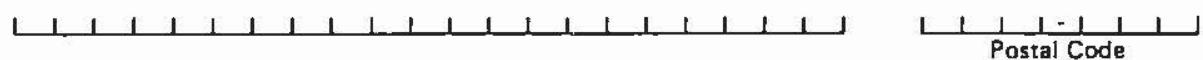

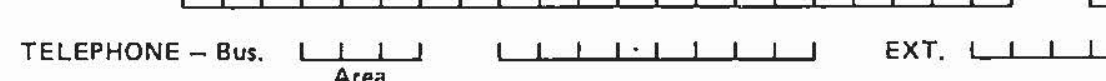

$$
\text { Res. } \frac{1}{\text { Area }} 1,1,1.1,1,1,
$$

TYPE OF MEMBERSHIP
(please check one)

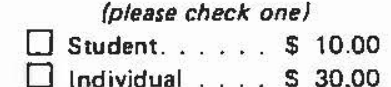

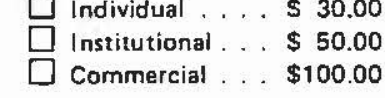

$$
\begin{aligned}
& \text { CANADIAN JOURNAL OF } \\
& \text { EOUCATIONAL COMMUNICATION } \\
& \square \text { is avaiabla to non-members on a } \\
& \text { subscription basis - lour issues } \\
& \text { per year ... \$330.00. }
\end{aligned}
$$

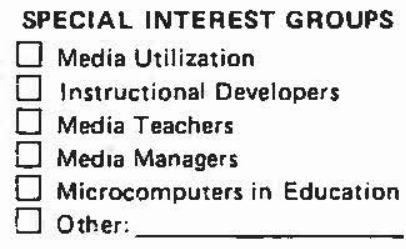

PLEASE COMPLETE THIS FOHM AND Guy Leger Asst. Superintendent of Curriculu Metropolitan Separate School
To Sheppard Ave. E.
Toronto, Ontario M2N 6 E8

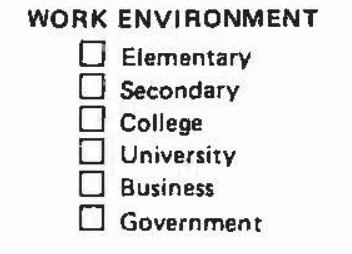

VOLUME 12, NUMBER 3, 1983



